\title{
Weibo-COV: A Large-Scale COVID-19 Social Media Dataset from Weibo
}

\author{
Yong Hu${ }^{\dagger}$, Heyan Huang ${ }^{\dagger}$, Anfan Chen ${ }^{\ddagger}$, Xian-Ling Mao ${ }^{\dagger}$ \\ ${ }^{\dagger}$ Beijing Institute of Technology \\ \{huyong, hhy63, maoxl\}@bit.edu.cn \\ $\ddagger$ University of Science and Technology of China \\ caf16@ustc.edu.cn
}

\begin{abstract}
With the rapid development of COVID-19 around the world, people are requested to maintain "social distance" and "stay at home". In this scenario, extensive social interactions transfer to cyberspace, especially on social media platforms like Twitter and Sina Weibo. People generate posts to share information, express opinions and seek help during the pandemic outbreak, and these kinds of data on social media are valuable for studies to prevent COVID-19 transmissions, such as early warning and outbreaks detection. Therefore, in this paper, we release a novel and finegrained large-scale COVID-19 social media dataset collected from Sina Weibo, named Weibo-COV ${ }^{1}$, contains more than 40 million posts ranging from December 1, 2019 to April 30, 2020. Moreover, this dataset includes comprehensive information nuggets like post-level information, interactive information, location information, and repost network. We hope this dataset can promote studies of COVID-19 from multiple perspectives and enable better and rapid researches to suppress the spread of this pandemic.
\end{abstract}

\section{Introduction}

At the beginning of this writing, COVID-19, an infectious disease caused by a coronavirus discovered in December, 2019, which also known as Severe Acute Respiratory Syndrome Coronavirus 2 (SARS-CoV-2), has caused 4,517,399 individuals infected globally, with a death toll of 308,515 (Doctor, 2020). Under the circumstance, the physical aspects of connection and human communication outside the household among people are limited considerably and mainly depend on digital devices like mobile phones or laptop computers (AbdulMageed et al., 2020). Due to it, people keep staying

\footnotetext{
${ }^{1}$ https://github.com/nghuyong/ weibo-public-opinion-datasets
}

at home and spending more time on social media communication, making social media a vital avenue for information sharing, opinions expression, and help-seeking (Lopez et al., 2020). All that makes social media platforms like Weibo, Twitter, Facebook and Youtube a more vital sources of information during the pandemic.

In previous studies, social media was considered a valuable data source for research against disease, like uncovering the dynamics of an emerging outbreak (Zhang and Centola, 2019), predicting the flu activity, and disease surveillance (Jeremy et al., 2009). For example, some studies facilitate better influenza surveillance, like early warning and outbreaks detection (Kostkova et al., 2014; De Quincey and Kostkova, 2009), forecasting estimates of influenza activity (Santillana et al., 2015), and predicting the actual number of infected cases (Lampos and Cristianini, 2010; Szomszor et al., 2010). Hence, it is necessary to retrieve the relevant social media datasets and make it freely accessible for researchers, for the sake of public goods and facilitating the relevant studies of COVID-19.

In this paper, we release a novel large-scale COVID-19 social media dataset from Sina Weibo (akin to Twitter), one of the most popular Chinese social media platforms in China. For convenience, we named it Weibo-COV, which contains more than 40 million posts from December 1, 2019 to April 30, 2020. Specifically, unlike the traditional API-based data collection methods, which limit large-scale data access, in this study, we construct a high-quality Weibo active user pool with 20 million active users from over 250 million users, then collect all active users' posts during that period, followed by filtering COVID-19 related posts with 179 representative keywords. Moreover, the fields of posts in the dataset are fine-grained, including post-level information, interactive information, location information and repost network, etc. We 


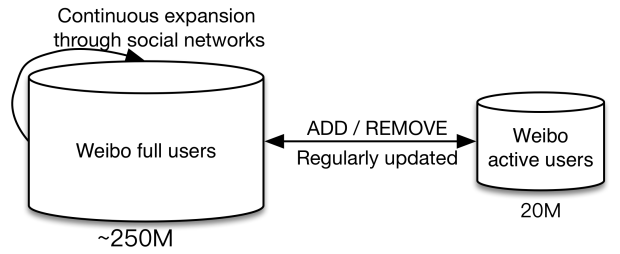

Figure 1: The construction of Weibo active user pool

hope this dataset can facilitate studies of COVID19 from multiple perspectives and enable better and rapid research to suppress the spread of this disease.

\section{Data Collection}

\subsection{Collection Strategy}

At present, given specified representative keywords and a specified period, there are two kinds of methods for constructing Weibo post datasets: (1) Advanced searching API given by Weibo; (2) Traversing all Weibo users, collecting all their posts during the specified period, and then filtering these posts with specified keywords.

However, due to the limitation of the Weibo search API, the first method limits keyword search output to 50 pages (around 1000 posts), making it difficult to build large-scale datasets. As for the second kinds of method, although we could build largescale datasets with almost no omissions, traversing all billions of Weibo users requires a very long time and massive bandwidth resources. Besides, a large proportion of Weibo users are inactive who may not post any posts in the specified period, and it makes meaningless to traverse their homepages.

To overcome these limitations, we propose a novel method to construct Weibo post datasets, which can build large-scale datasets with high construction efficiency. Specifically, we first build and dynamically maintain a high-quilty Weibo active user pool (just a small part of all users), and then we only traverse the home pages of these users and collect all their posts with specified keywords in a required period.

\subsection{Weibo Active User Pool}

As shown in Figure 1, based on initial seed users and continuous expansion through social relationships, we first collect more than 250 million Weibo users. Then we define that Weibo active users should meet the following two requirements: (1) The number of followers, fans and posts are all
Table 1: The field description of the dataset

\begin{tabular}{|c|c|}
\hline Field & Description \\
\hline -id & $\begin{array}{l}\text { the unique identifier of the } \\
\text { post }\end{array}$ \\
\hline crawl_time & $\begin{array}{l}\text { crawling time of the post, } \\
\text { which indicates when we re- } \\
\text { trieve the specific post from } \\
\text { Weibo (GMT+8) }\end{array}$ \\
\hline created_at & $\begin{array}{l}\text { creating time of the post } \\
(\mathrm{GMT}+8)\end{array}$ \\
\hline like_num & $\begin{array}{l}\text { the number of like at the } \\
\text { crawling time }\end{array}$ \\
\hline repost_num & $\begin{array}{l}\text { the number of repost at the } \\
\text { crawling time }\end{array}$ \\
\hline comment_num & $\begin{array}{l}\text { the number of comment at } \\
\text { the crawling time }\end{array}$ \\
\hline content & the content of the post \\
\hline origin_weibo & $\begin{array}{l}\text { the id of the origin post, } \\
\text { only not empty when the } \\
\text { post is a repost one }\end{array}$ \\
\hline geo_info & $\begin{array}{l}\text { information of latitude and } \\
\text { longitude, only not empty } \\
\text { when the post contains the } \\
\text { location information }\end{array}$ \\
\hline
\end{tabular}

more than 50; (2) The latest post is posted in 30 days. Therefore, we can build and dynamically maintain a Weibo active user pool from all collected Weibo users. Finally, the constructed Weibo active user pool contains 20 million users, accounting for $8 \%$ of the total number of Weibo users.

\subsection{COVID-19 posts Collection}

According to the collection strategies described in Section 2.1, we set the period from 00:00 December 1, 2019 (GMT+8, the date of the first confirmed infected case of COVID-19) to 23:59 April 30, 2020 (GMT+8). Following best practices of text retrieval and content analysis (Chen et al., 2019; Zhang et al., 2020; Li et al., 2020, 2019; Shen et al., 2020; Lacy et al., 2015), we generate a list of 179 keywords related to COVID-19 through close observation of Weibo posts every day from late January to April, 2020. These keywords are comprehensive, covering related terms such as coronavirus and pneumonia, as well as specific locations (e.g., "Wuhan"), drugs (e.g., "remdesivir"), preventive measures (e.g., "mask"), experts and doctors (e.g., "Zhong Nanshan"), government policy (e.g, "postpone the reopening of school") and others (see 


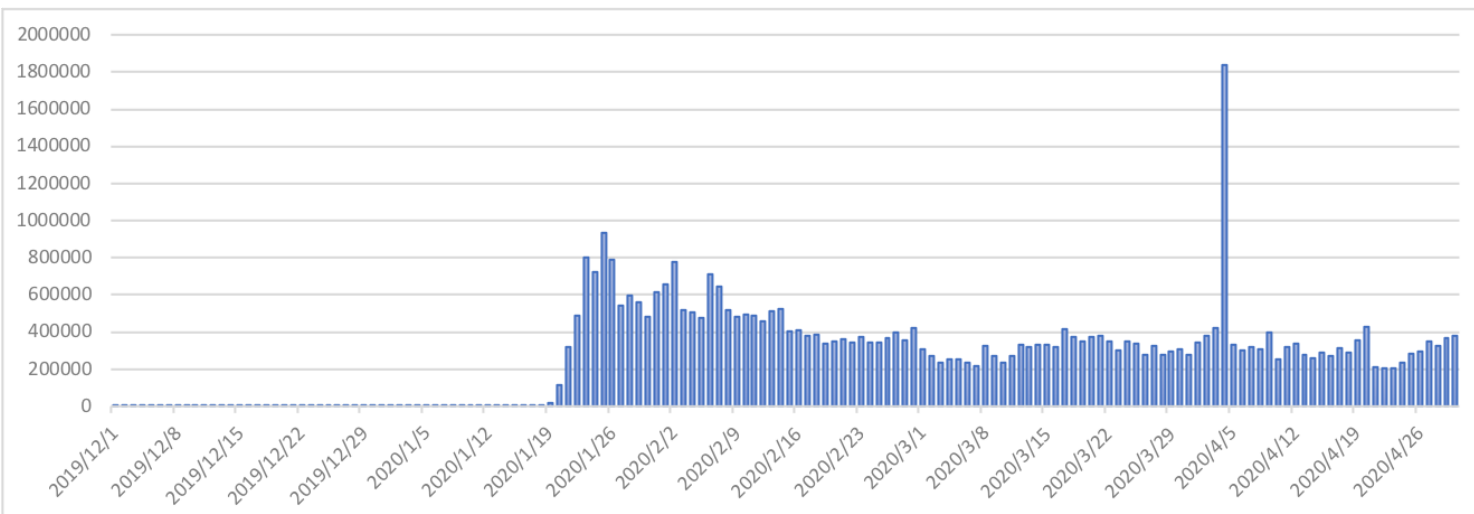

Figure 2: The daily distribution of Weibo-COV

Appendix.1 for the complete list).

As a result, based on 20 million Weibo active user pool, we first collect a total of $692,792,816$ posts posted by these users in the specified period. Subsequently, we filter these posts by 179 keywords, along with duplication by unique post id. Finally, 40,893,953 posts are retained in our dataset.

Besides, some points should be noted that: (1) This COV-Weibo dataset can be retrieved with a single full download from our released website after submitting a data use agreement (DUA). (2) All the users' identifiable information such as user id, user name, post id, etc. have been converted into an unrecognizable status and can not be traced to protect the privacy of individual users, which is consistent with the presence of personally identifiable information (PII). Also, it is conducted by the terms-of-use of Weibo. (3) We declare the ownership of the source data to the corresponding Weibo users because Weibo users created this kind of public UGC (User Generated Content), and we only collect, organize and filter them. (4) Our Institutional Review Board (IRB) is under processing and waiting to be signed.

\section{Data Properties}

\subsection{The Inner Structure of the Dataset}

As shown in Table 1, fields of posts in the dataset are very rich, covering the basic information (_id, crawl_time, content), interactive information (like_num, repost_num, comment_num), location information (geo_info) and repost network (origin_weibo). Therefore, various kind of studies related to infectious diseases can be conducted based on this dataset, such as the impact
Table 2: The basic statistics of Weibo-COV

\begin{tabular}{ccc}
\hline \#ALL & \#GEO & \#Original \\
\hline $40,893,953$ & $1,119,608$ & $8,284,992$ \\
\hline
\end{tabular}

on people's daily life, the early characteristics of the disease, and government anti-epidemic policies.

\subsection{Basic Statistic}

As shown in Table 2, Weibo-COV contains a total number of 40,893,953 posts. Among these posts, there are $1,119,608$ posts with geographic location information (accounting for 2.7\%) and 8,284,992 original posts (accounting for $20.26 \%$ ).

\subsection{Daily Distribution}

The distribution of the number of posts by day is shown in Figure 2. It can be noticed that from December 1, 2019 to January 18, 2020, the number of COVID-19 related posts is tiny (less than 10K) and may include some noise data. Since January 19, 2020, the number of COVID-19 related posts expanded rapidly and maintained at least 200,000 per day.

Note that the data on April 4, 2020, is particularly striking, and the number of posts on that day exceeds 1.8 million. A reasonable explanation could be that day was Chinese Tomb Sweeping Festival, a national mourning was held for the compatriots who died in the epidemic, people posted or reposted many mourning posts on Weibo on that day, which drawn extensive attention and generated a massive number of posts.

\subsection{GEO Distribution}

As shown in Figure 3, we plot the location distribution of posts with geoinformation on April 4, 


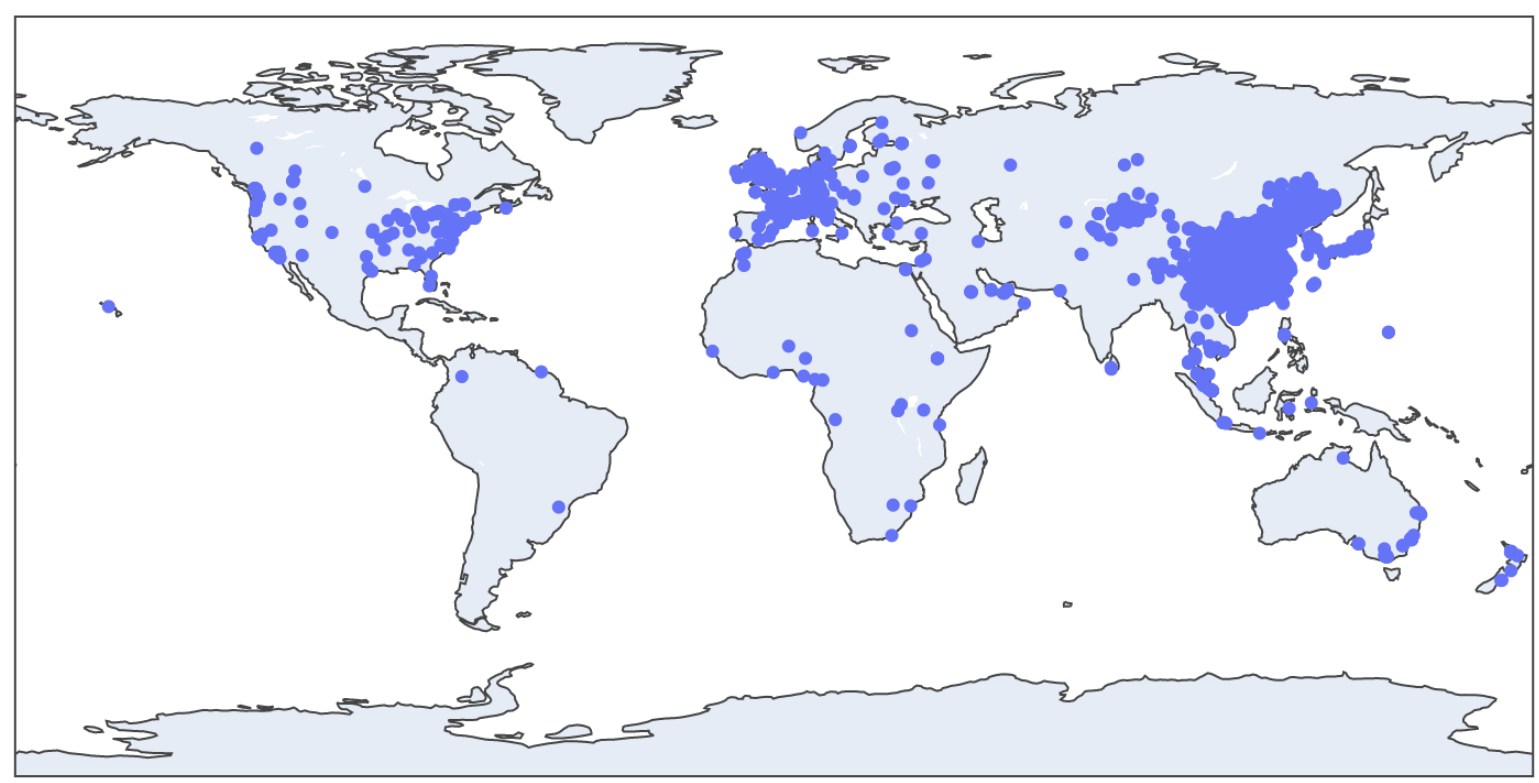

Figure 3: Distribution of location information of posts on April 4, 2020

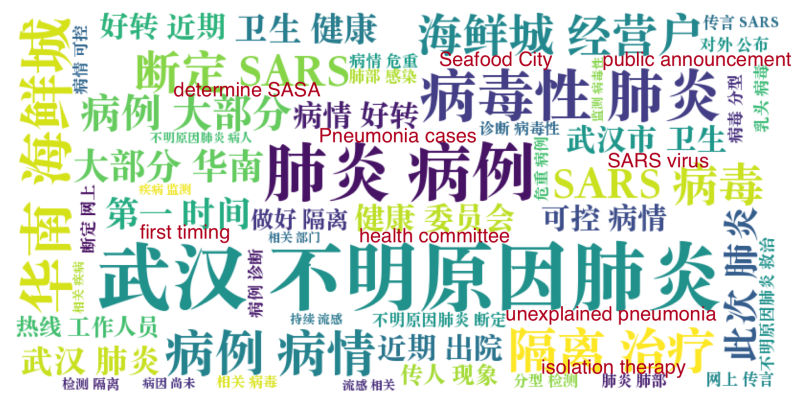

(a) 2019-12-31

resumption of work and production

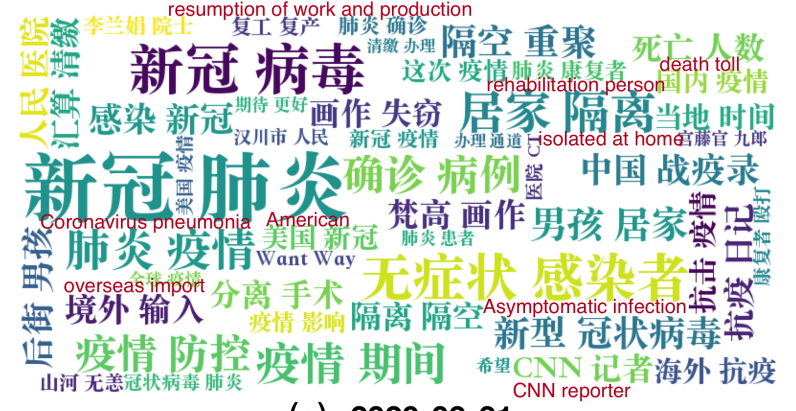

(c) 2020-03-31

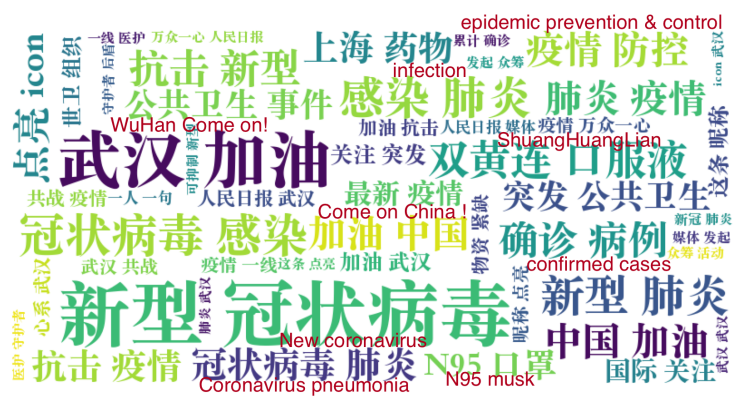

(b) 2020-01-31

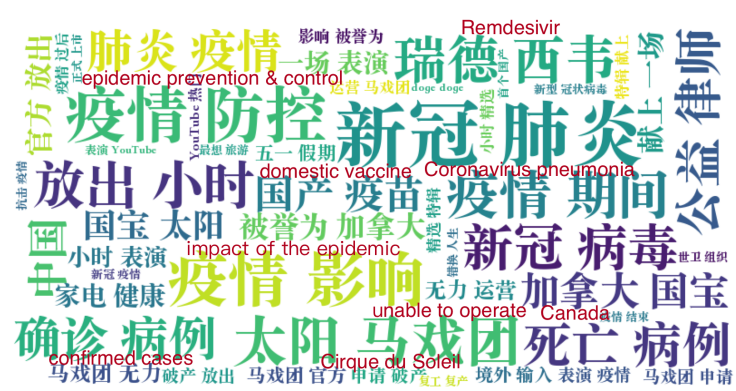

(d) $2020-04-30$

Figure 4: Word cloud of posts in four days and some words are translated in red

2020. It can be seen that the distribution of posts is mainly in China. There is also a part of posts distributed oversea, including major countries in Asia, Europe, Australia and America. The possible reasons could be that with the development of economic globalization, more and more Chinese people go abroad for work/living, and more and more foreigners start to use Weibo, promoting a large proportion of oversea Weibo users.

Therefore, our dataset can provide insight into the nationwide and global impact of the pandemic.

\subsection{Word Cloud}

We select four days of posts data at different stages of the epidemic development and draw word clouds. As shown in Figure 4 (a), in the early days, people even did not know the characteristics of the virus and, however, the government began to take preliminary actions (e.g., "unexplained pneumonia" and "health committee"). Later, as shown in Figure 4 (b), people learned that the virus is a new coronavirus and learned preventive methods and 
medicines (e.g., "new coronavirus", "N95 mask" and "ShuangHuang Lian"). Then, as shown in Figure 4 (c), governments took strict isolation rules and strove to prevent imported cases from abroad (e.g., "isolated at home" and "overseas import"). By the end of April, as shown in Figure 4 (d), the virus has had many impacts on people's lives. Fortunately, research on vaccines and medicines has been ongoing and made significant progress (e.g., "Remdesivir").

Therefore, this dataset runs through the whole development stages of COVID-19, including impacts of the disease on all aspects of society.

\section{Related Work}

Several works have focused on creating social media datasets for enabling COVID-19 research. (Chen et al., 2020), (Lopez et al., 2020) and (AbdulMageed et al., 2020) have already released datasets collected from Twitter. However, these datasets are mainly in English, and posts generated by Chinese, the epicentre of the early development of COVID19, also deserves close attention. Therefore, collecting the Weibo datasets are also valuable and can provide additional supplements for researches.

Only one dataset proposed by (Gao et al., 2020) includes posts from Weibo, but their method relies on Weibo advanced search API provided by Weibo, which hinders them from collecting largescale posts as we mentioned above. Compared with our dataset, the data size (less than 200K), the time period (from January 20, 2020 to March 24, 2020), and the number of keywords (only four keywords) of this Weibo dataset seem much smaller and narrow.

\section{Conclusion}

In this paper, we release Weibo-COV, a first largescale COVID-19 posts dataset from Weibo. The dataset contains more than 40 million posts from December 1, 2019 to April 30, 2020, with rich field information. We hope this dataset could promote and facilitate related studies on COVID-19.

\section{Acknowledgments}

We would like to thank all the reviewers for their helpful suggestions and comments. This work is supported by the National Key R\&D Plan (No. 2016QY03D0602), NSFC (No. U19B2020, 61772076, 61751201 and 61602197), NSFB (No. Z181100008918002), the 25th department funding of USTC (No. DA2110251001) and 2019 New Humanities Funding of USTC (No. YD2110002015).

\section{References}

Muhammad Abdul-Mageed, AbdelRahim Elmadany, Dinesh Pabbi, Kunal Verma, and Rannie Lin. 2020. Mega-cov: A billion-scale dataset of 65 languages for covid-19.

Emily Chen, Kristina Lerman, and Emilio Ferrara. 2020. Tracking social media discourse about the covid-19 pandemic: Development of a public coronavirus twitter data set. JMIR Public Health and Surveillance, 6(2):e19273.

Zhuo Chen, Chris Chao Su, and Anfan Chen. 2019. Top-down or bottom-up? a network agenda-setting study of chinese nationalism on social media. Journal of Broadcasting \& Electronic Media, 63(3):512533.

Ed De Quincey and Patty Kostkova. 2009. Early warning and outbreak detection using social networking websites: The potential of twitter. In International Conference on Electronic Healthcare, pages 21-24. Springer.

Dingxiang Doctor. 2020. Covid-19 global pandemic real-time reports. https://ncov.dxy.cn/ ncovh5/view/pneumonia.

Zhiwei Gao, Shuntaro Yada, Shoko Wakamiya, and Eiji Aramaki. 2020. Naist covid: Multilingual covid-19 twitter and weibo dataset.

Jeremy, Ginsberg, Matthew, H, Mohebbi, Rajan, S, Patel, Lynnette, and Brammer and. 2009. Detecting influenza epidemics using search engine query data. Nature.

Patty Kostkova, Martin Szomszor, and Connie St. Louis. 2014. \# swineflu: The use of twitter as an early warning and risk communication tool in the 2009 swine flu pandemic. ACM Transactions on Management Information Systems (TMIS), 5(2):125 .

Stephen Lacy, Brendan R Watson, Daniel Riffe, and Jennette Lovejoy. 2015. Issues and best practices in content analysis. Journalism \& Mass Communication Quarterly, 92(4):791-811.

Vasileios Lampos and Nello Cristianini. 2010. Tracking the flu pandemic by monitoring the social web. In 2010 2nd international workshop on cognitive information processing, pages 411-416. IEEE.

Pengxiang Li, Hichang Cho, Yuren Qin, and Anfan Chen. 2020. \# metoo as a connective movement: Examining the frames adopted in the anti-sexual harassment movement in china. Social Science Computer Review, page 0894439320956790. 
Yang Li, Chen Luo, and Anfan Chen. 2019. The evolution of online discussions about gmos in china over the past decade: Changes, causes and characteristics. Cultures of Science, 2(4):311-325.

Christian E. Lopez, Malolan Vasu, and Caleb Gallemore. 2020. Understanding the perception of covid-19 policies by mining a multilanguage twitter dataset.

Mauricio Santillana, André T Nguyen, Mark Dredze, Michael J Paul, Elaine O Nsoesie, and John S Brownstein. 2015. Combining search, social media, and traditional data sources to improve influenza surveillance. PLoS computational biology, 11(10).

Cuihua Shen, Anfan Chen, Chen Luo, Wang Liao, Jingwen Zhang, and Bo Feng. 2020. Reports of own and others' symptoms and diagnosis on social media predict covid-19 case counts in mainland china. arXiv preprint arXiv:2004.06169.

Martin Szomszor, Patty Kostkova, and Ed De Quincey. 2010. \# swineflu: Twitter predicts swine flu outbreak in 2009. In International conference on electronic healthcare, pages 18-26. Springer.

Jingwen Zhang and Damon Centola. 2019. Social networks and health: new developments in diffusion, online and offline. Annual Review of Sociology, 45:91-109.

Xing Zhang, Elmie Nekmat, and Anfan Chen. 2020. Crisis collective memory making on social media: A case study of three chinese crises on weibo. Public Relations Review, 46(4):101960. 


\section{A Appendices}

\section{A.1 Covid-19 Related Keywords}

Table 3: The list of selected keywords related to COVID-19

\begin{tabular}{|c|c|}
\hline Keywords & Translations \\
\hline 冠状 & Coronavirus \\
\hline Cov-19 & Cov-19 \\
\hline 新冠 & Coronavirus \\
\hline 感染人数 & Infected cases \\
\hline N95 & N95 Mask \\
\hline 大众畜牧野味店 & Dazhong wildlife restaurant \\
\hline 华南野生市场 & South China wild market \\
\hline 管轶 & Guan Yi \\
\hline 武汉病毒所 & Wuhan Institute of Virology \\
\hline $\mathrm{CDC}$ & Center for Disease Control and Prevention \\
\hline 中国疾病预防控制中心 & Chinese Center for Disease Control and Prevention \\
\hline 疾控中心 & Center for Disease Control and Prevention \\
\hline \#2019nCoV & \#2019nCoV \\
\hline 双黄连 AND 抢购 & Shuanghuanglian AND Rush to buy \\
\hline 双黄连 AND 售磬 & Shuanghuanglian AND Sold out \\
\hline 武汉卫健委 & Wuhan Municipal Health Committee \\
\hline 湖北卫健委 & Health Commission of Hubei Province \\
\hline \#nCoV & \#nCoV \\
\hline PHEIC & PHEIC \\
\hline 疫情 & Epidemic outbreak \\
\hline 火神山 & Huoshen Shan hospital \\
\hline 雷神山 & Leishen Shan hospital \\
\hline 钟南山 & Zhong Nanshan \\
\hline Coronavirus & Coronavirus \\
\hline Remdesivir & Remdesivir \\
\hline 瑞德西韦 & Remdesivir \\
\hline 感染 AND 例 & Infected AND cases \\
\hline 武汉 AND 封城 & Wuhan AND Lockdown \\
\hline 高福 & George Fu Gao \\
\hline 王延轶 & Wang Yanyi \\
\hline 舒红兵 & Shu Hongbing \\
\hline 协和医院 & Xiehe Hospital \\
\hline 武汉 AND 隔离 & Wuhan AND Quarantine \\
\hline 李文亮 AND 医生 & Doctor AND Li Wenliang \\
\hline 云监工 & Supervising work on cloud \\
\hline 武汉仁爱医院 & Wuhan Ren'ai Hospital \\
\hline 黄冈 AND 感染者 & Huanggang AND Infected cases \\
\hline 孝感 AND 感染者 & Xiaogan AND Infected cases \\
\hline 居家隔离 & Isolated at home \\
\hline 防护服 & Protective Clothing \\
\hline 隔离14天 & Isolation AND 14 days \\
\hline 潜伏期 AND 24天 & Incubation period AND 24 days \\
\hline 潜伏期 AND 14天 & Incubation period AND 14 days \\
\hline 国际公共卫生紧急事件 & International Public Health Emergencies \\
\hline
\end{tabular}


Table 3 - continued from previous page

\begin{tabular}{|c|c|}
\hline Keywords & Translations \\
\hline 方舱医院 AND 武汉 & FangCang Hospital AND Wuhan \\
\hline 一省包一市 & one province gives a hand to one Hubei city \\
\hline 晋江毒王 & Super spreader of COVID-19 in Jinjiang \\
\hline 超级传播者 & Super spreader \\
\hline 湖北 AND 王晓东 & Hubei AND Wang Xiaodong \\
\hline 蒋超良 & Jiang Chaoliang \\
\hline 李文亮 & Li Wenliang \\
\hline 千里投毒 & Spread Virus from a thousand miles \\
\hline 武汉病毒研究 & Virology research in Wuhan \\
\hline 武汉 AND 李医生 & Wuhan AND Li Wenliang \\
\hline 国家疾控中心 & Chinese Center for Disease Control and Prevention \\
\hline 武汉 AND 疫苗 & Wuhan AND Vaccine \\
\hline 武汉 AND 征用宿舍 & Wuhan AND Requisitioned students' dormitory \\
\hline 周佩仪 & Zhou Peiyi \\
\hline 武汉中心医院 & The Central Hospital of Wuhan \\
\hline 张晋 AND 卫健委 & Zhang Jin AND Health Commission \\
\hline 张晋 AND 卫生将康委员会 & Zhang Jin AND Health Commission \\
\hline 刘英姿 AND 卫健委 & Liu Yingzi AND Health Commission \\
\hline 刘英姿 AND 卫生健康委员会 & Liu Yingzi AND Health Commission \\
\hline 王贺胜 AND 卫健委 & Wang Hesheng AND Health Commission \\
\hline 王贺胜 AND 卫生健康委员会 & Wang Hesheng AND Health Commission \\
\hline 复工 & Enterprise work resuming \\
\hline 中小企业 AND 困境 & Small and medium-sized enterprise AND Dilemma \\
\hline 武汉 AND 死亡病例 & Wuhan AND Death cases \\
\hline 武汉 AND 感染病例 & Wuhan AND Infection cases \\
\hline 湖北 AND 死亡病例 & Hubei AND Death cases \\
\hline 湖北 AND 感染病例 & Hubei AND Infected cases \\
\hline 中国 AND 死亡病例 & China AND Death cases \\
\hline 中国 AND 感染病例 & China AND Infected cases \\
\hline 潜伏期 & Incubation Period \\
\hline 北京 AND 病例 & Beijing AND Cases \\
\hline 天津 AND 病例 & Tianjin AND Cases \\
\hline 河北 AND 病例 & Hebei AND Cases \\
\hline 辽宁 AND 病例 & Liaoning AND Cases \\
\hline 上海 AND 病例 & Shanghai AND Cases \\
\hline 江苏 AND 病例 & Jiangsu AND Cases \\
\hline 浙江 AND 病例 & Zhejiang AND Cases \\
\hline 福建 AND 病例 & Fujian AND Cases \\
\hline 山东 AND 病例 & Shandong AND Cases \\
\hline 广东 AND 病例 & Guangdong AND Cases \\
\hline 海南 AND 病例 & Hainan AND Cases \\
\hline 山西 AND 病例 & Shanxi AND Cases \\
\hline 内蒙古 AND 病例 & Inner Mongolia AND Cases \\
\hline 吉林 AND 病例 & Jilin AND Cases \\
\hline 黑龙江 AND 病例 & Heilongjiang AND Cases \\
\hline 安徽 AND 病例 & Anhui AND Cases \\
\hline 江西 AND 病例 & Jiangxi AND Cases \\
\hline 河南 AND 病例 & Henan AND Cases \\
\hline
\end{tabular}


Table 3 - continued from previous page

\begin{tabular}{|c|c|}
\hline Keywords & Translations \\
\hline 湖北 AND 病例 & Hubei AND Cases \\
\hline 湖南 AND 病例 & Hunan AND Cases \\
\hline 广西 AND 病例 & Guangxi AND Cases \\
\hline 四川 AND 病例 & Sichuan AND Cases \\
\hline 贵州 AND 病例 & Guizhou AND Cases \\
\hline 云南 AND 病例 & Yunnan AND Cases \\
\hline 西藏 AND 病例 & Tibet AND Cases \\
\hline 陕西 AND 病例 & Shanxi AND Cases \\
\hline 甘肃 AND 病例 & Gansu AND Cases \\
\hline 青海 AND 病例 & Qinghai AND Cases \\
\hline 宁夏 AND 病例 & Ningxia AND Cases \\
\hline 新疆 AND 病例 & Xinjiang AND Cases \\
\hline 香港 AND 病例 & Hong Kong AND Cases \\
\hline 澳门 AND 病例 & Macau AND Cases \\
\hline 台湾 AND 病例 & Taiwan AND Cases \\
\hline ECOM & Extracorporeal Membrane Oxygenation \\
\hline sars-cov-2 & sars-cov-2 \\
\hline 复学 & Resumption of schooling \\
\hline 护目镜 & Goggles \\
\hline 核酸检测 & nucleic acid testing (NAT) \\
\hline COVID-19 & COVID-19 \\
\hline 2019-nCoV & 2019-nCoV \\
\hline 疑似 AND 病例 & Suspicious cases \\
\hline 无症状 & Asymptomatic Patients \\
\hline 累计病例 & Cumulative confirmed cases \\
\hline 境外输入 & imported cases of NCP \\
\hline 累计治愈 & Cumulative cured cases \\
\hline 绥芬河 & Sui Fenhe \\
\hline 舒兰 & Shu Lan \\
\hline 健康码 & Health QR code \\
\hline 出入码 & Community Access Code \\
\hline 返校 & Back to Camp \\
\hline 美国 AND 例 & USA AND Cases \\
\hline 西班牙 AND 例 & Spain AND Cases \\
\hline 新加坡 AND 例 & Singapore AND Cases \\
\hline 加拿大 AND 例 & Canada AND Cases \\
\hline 英国 AND 例 & UK AND Cases \\
\hline 印度 AND 例 & India AND Cases \\
\hline 日本 AND 例 & Japan AND Casess \\
\hline 韩国 AND 例 & South Korea AND Cases \\
\hline 德国 AND 例 & Germany AND Cases \\
\hline 法国 AND 例 & France AND Cases \\
\hline 意大利 AND 例 & Italy AND Cases \\
\hline 新增 AND 例 & New AND Cases \\
\hline 人工膜肺 & Extracorporeal Membrane Oxygenation \\
\hline 双盲测试 & Double Blind Test \\
\hline 疫苗 & Vaccine \\
\hline 小区出入证 & Community Entry card \\
\hline
\end{tabular}


Table 3 - continued from previous page

\begin{tabular}{|c|c|}
\hline Keywords & Translations \\
\hline 战疫 & Anti-COVID-19 \\
\hline 抗疫 & Anti-COVID-19 \\
\hline 湖北卫健委 AND 免职 & Health commission of Hubei Province AND Remove from the position \\
\hline 发热患者 & Fever patients \\
\hline 延迟开学 & Postpone the reopening of school \\
\hline 开学时间 AND 不得早于 & The start time of school AND Not earlier than \\
\hline 累计死亡数 & Cumulative deaths \\
\hline 疑似病例 & Suspicious cases \\
\hline 入户排查 & Household troubleshoot \\
\hline 武汉 AND 肺炎 & Wuhan AND Pneumonia \\
\hline 新型肺炎 & Novel Pneumonia \\
\hline 不明原因肺炎 & Pneumonia of unknown cause \\
\hline 野味肺炎 & Wildlife pneumonia \\
\hline 出门 AND 戴口罩 & Going out AND Wear mask \\
\hline 3M AND 口罩 & N95 AND Mask \\
\hline KN95 AND 口罩 & 3M AND Mask \\
\hline 新肺炎 & Novel Pneumonia \\
\hline \#2019nCoV & \#2019nCoV \\
\hline 新型肺炎 AND 死亡 & Novel Pneumonia AND Death \\
\hline 新型肺炎 AND 感染 & Novel Pneumonia Infection \\
\hline 武汉 AND 肺炎 AND 谣言 & Wuhan AND Pneumonia AND Rumors \\
\hline 8名散布武汉肺炎谣言 & Eight people AND Spread rumors of Wuhan pneumonia \\
\hline 黄冈 AND 新肺炎 & Huanggang AND Novel Pneumonia \\
\hline 孝感 AND 新肺炎 & Xiaogan AND Novel Pneumonia \\
\hline 居家隔离 & Isolated at home \\
\hline 武汉中心医院 AND 新型肺炎 & The Central Hospital of Wuhan AND Novel Pneumonia \\
\hline 武汉肺炎 & Wuhan Pneumonia \\
\hline 企业复工 & Enterprise work resuming \\
\hline 眊积口罩 & Hoarding mask \\
\hline 零号病人 & Zero Patient \\
\hline 黄燕玲 & Huang Yanling \\
\hline 病毒源头 & Oringin of Cov-19 \\
\hline 电子烟肺炎 AND 新型冠状 & E-cigarette Pneumonia AND Coronavirus \\
\hline 病毒战 & Virus War \\
\hline 病毒 AND 实验室泄露 & Virus AND laboratory leakage \\
\hline 比尔盖茨 AND 疫苗牟利 & Bill Gates AND Vaccine for profit \\
\hline 美国细菌实验室 & US Army Bacterial Laboratory \\
\hline 确诊 & Confired Infencted COV-19 cases \\
\hline & pandem \\
\hline
\end{tabular}

